\title{
Human T-Lymphotropic Virus Type 1 (Htlv-1): a new subgroup within the cosmopolitan subtype
}

\author{
María Eirin ${ }^{1}$, Leandro Jones², Carolina Berini ${ }^{1}$, Darío Dilernia ${ }^{1}$, Cecilia Delfino ${ }^{1}$, Mirna Biglione $^{1 *}$ \\ From 15th International Conference on Human Retroviruses: HTLV and Related Viruses \\ Leuven and Gembloux, Belgium. 5-8 June 2011
}

\section{Introduction}

HTLV-1 is classified in seven subtypes (a-g) most of them restricted to specific regions (b-e), while the Cosmopolitan subtype (a) is worldwide distributed. Cosmopolitan subtype has experimented a degree of molecular diversity giving rise to five subgroups: Transcontinental (A), Japanese (B), West African (C), North African (D) and Black Peruvian (E).

\section{Objective}

to confirm the classification of four HTLV-1 highly divergent strains as a new subgroup within the Cosmopolitan subtype.

\section{Materials and methods}

LTR sequences from 65 HTLV-1 positive Buenos Aires residents were retrospectively studied. Phylogeny of LTR region was studied by three different methods (ML, MP and $\mathrm{NJ}$ ). A similitude index (SI) was estimated as the mean number of nucleotide substitutions from each subgroup (intra-subgroup) or between sequences from a given subgroup against all from other subgroups (intersubgroup) (script described in the R Statistical Package Language http://www.R-project.org).

\section{Results}

The three phylogenetic methods were consistent, showing a well supported monophyletic clade that included two Peruvian sequences clustering with two references (Bl3 from Peru and Br4 from Brazil) previously described as divergent, branching off all known subgroups ( $82 \%$ bootstrap, ML). The similitude analysis showed a SI intra-subgroup similar to those obtained

\footnotetext{
* Correspondence: mbiglione@fmed.uba.ar

${ }^{1}$ Centro Nacional de Referencia para el SIDA, Facultad de Medicina, UBA, Buenos Aires, Argentina

Full list of author information is available at the end of the article
}

for A-D subgroups and a SI inter-subgroup similar to subgroups A and D. Following nomenclature, it was named subgroup $F$.

\section{Conclusions}

This study confirms the existence of a highly divergent monophyletic clade within the Cosmopolitan subtype composed of sequences from Peruvian and Brazilian individuals and suggest that more studies should be performed in this South-American area where the last subgroups ( $\mathrm{E}$ and $\mathrm{F}$ ) has been detected.

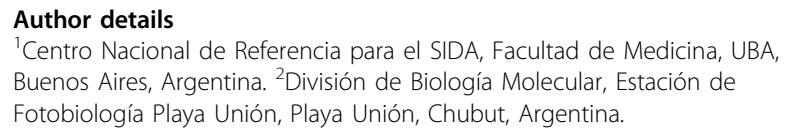

Published: 6 June 2011

doi:10.1186/1742-4690-8-S1-A75

Cite this article as: Eirin et al:: Human T-Lymphotropic Virus Type 1

(Htlv-1): a new subgroup within the cosmopolitan subtype. Retrovirology 2011 8(Suppl 1):A75.

Submit your next manuscript to BioMed Central and take full advantage of:

- Convenient online submission

- Thorough peer review

- No space constraints or color figure charges

- Immediate publication on acceptance

- Inclusion in PubMed, CAS, Scopus and Google Scholar

- Research which is freely available for redistribution
C Biomed Central

C 2011 Eirin et al; licensee BioMed Central Ltd. This is an open access article distributed under the terms of the Creative Commons Attribution License (http://creativecommons.org/licenses/by/2.0), which permits unrestricted use, distribution, and reproduction in any medium, provided the original work is properly cited. 